April 2003 - NREL/CP-520-33229

\title{
Evidence of the Meyer-Neldel Rule in InGaAsN Alloys: Consequences for Photovoltaic Materials
}

\section{Preprint}

S.W. Johnston and R.S. Crandall

To be presented at the 2003 Materials Research Society Spring Meeting San Francisco, California April 21-25, 2003

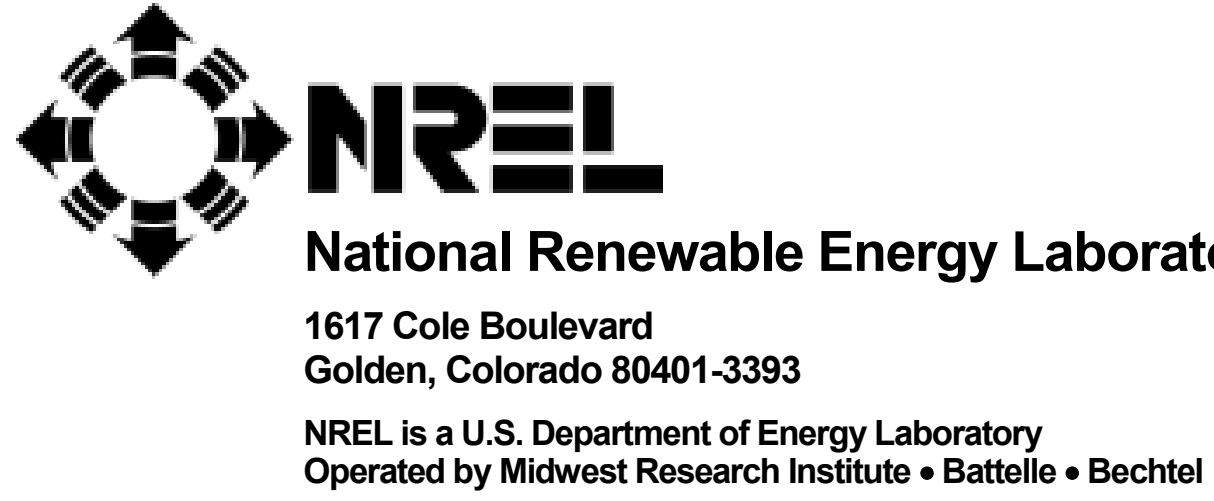




\section{NOTICE}

The submitted manuscript has been offered by an employee of the Midwest Research Institute (MRI), a contractor of the US Government under Contract No. DE-AC36-99G010337. Accordingly, the US Government and MRI retain a nonexclusive royalty-free license to publish or reproduce the published form of this contribution, or allow others to do so, for US Government purposes.

This report was prepared as an account of work sponsored by an agency of the United States government. Neither the United States government nor any agency thereof, nor any of their employees, makes any warranty, express or implied, or assumes any legal liability or responsibility for the accuracy, completeness, or usefulness of any information, apparatus, product, or process disclosed, or represents that its use would not infringe privately owned rights. Reference herein to any specific commercial product, process, or service by trade name, trademark, manufacturer, or otherwise does not necessarily constitute or imply its endorsement, recommendation, or favoring by the United States government or any agency thereof. The views and opinions of authors expressed herein do not necessarily state or reflect those of the United States government or any agency thereof.

Available electronically at http://www.osti.gov/bridge

Available for a processing fee to U.S. Department of Energy and its contractors, in paper, from:

U.S. Department of Energy

Office of Scientific and Technical Information

P.O. Box 62

Oak Ridge, TN 37831-0062

phone: 865.576.8401

fax: 865.576.5728

email: reports@adonis.osti.gov

Available for sale to the public, in paper, from:

U.S. Department of Commerce

National Technical Information Service

5285 Port Royal Road

Springfield, VA 22161

phone: 800.553 .6847

fax: 703.605.6900

email: orders@ntis.fedworld.gov

online ordering: http://www.ntis.gov/ordering.htm

Printed on paper containing at least $50 \%$ wastepaper, including $20 \%$ postconsumer waste 


\title{
Evidence of the Meyer-Neldel Rule in InGaAsN Alloys: Consequences for Photovoltaic Materials
}

Steven W. Johnston and Richard S. Crandall

National Renewable Energy Laboratory,

Golden, CO 80401, U.S.A.

\begin{abstract}
We present data showing the potential adverse effects on photovoltaic device performance of all traps in InGaAsN. Deep-level transient spectroscopy measurements were performed on InGaAsN samples grown by both metal-organic chemical vapor deposition and RF plasmaassisted molecular-beam epitaxy. For each growth technique, we studied samples with varying nitrogen composition ranging from $0 \%$ to $2.2 \%$. A deep hole trap with activation energy ranging between 0.5 and $0.8 \mathrm{eV}$ is observed in all samples. These data clearly obey the Meyer-Neldel rule, which states that all traps have the same emission rate at the isokinetic temperature. A fit of our trap data gives an isokinetic temperature of $350 \mathrm{~K}$. We find that the emission time for all deep hole traps is on the order of milliseconds at room temperature. This means that both deep and shallow traps emit slowly at the operating temperature of solar cells - thus, the traps can be recombination centers.
\end{abstract}

\section{INTRODUCTION}

Adding nitrogen to GaAs initially reduces the bandgap [1-3]. This alloy can be grown epitaxially on GaAs, and lattice-matching can be improved by also adding In [4]. With about $2 \%$ $\mathrm{N}$ and $6 \% \mathrm{In}$, a 1-eV bandgap material lattice-matched to GaAs can be grown [4,5]. These properties are advantageous for developing a four-junction high-efficiency solar cell, consisting of GaInP, GaAs, InGaAsN, and Ge. Such a structure has an ideal AM0 efficiency of 41\% [6], but to date, poor minority-carrier properties have limited the material's usefulness in multijunction cells $[5,7]$.

Deep-level transient spectroscopy (DLTS) is a powerful technique for characterizing material defects and providing information to identify lifetime-killing defects that degrade device performance. DLTS data have been reported on both metal-organic chemical-vapor-deposited (MOCVD) and RF plasma-assisted molecular-beam epitaxy (MBE) InGaAsN alloys. Krispin et al. report several hole traps in MBE-grown material having activation energies of 0.16 to 0.17 , 0.35 to $0.36,0.39,0.55$, and $0.69 \mathrm{eV}$ [8]. The larger activation-energy traps $(0.55$ and $0.69 \mathrm{eV})$ appear in the largest concentrations. They assign the $0.55-\mathrm{eV}$ level to an $\mathrm{Fe}_{\mathrm{Ga}}$ (Fe on a Ga site) substitutional defect, and the $0.69-\mathrm{eV}$ level to $\mathrm{a} \mathrm{Ga}_{\mathrm{As}}{ }^{-/ 2-}$ (charge-state change) anti-site defect [9]. Chen et al. [10] report a hole trap in N-implanted GaAs and suggest that this level at $0.545 \mathrm{eV}$ is a nitrogen-related acceptor defect. Kwon et al. [11] and Kaplar et al. [12] have reported hole traps with activation energies of $0.10,0.23$, and $0.48 \mathrm{eV}$, along with a broad peak corresponding to $\sim 0.5 \mathrm{eV}$ in MOCVD-grown material. Kaplar et al. [13] also report activation energies of 0.37 , 0.51 , and $0.71 \mathrm{eV}$ in MBE material. Johnston [14] reported a deep hole-trap ranging in activation energy from 0.61 to $0.79 \mathrm{eV}$ in MOCVD samples of varying In and $\mathrm{N}$ composition; using these data plus data from similar MBE-grown samples, we will show evidence of the Meyer-Neldel-rule behavior. 


\section{EXPERIMENTAL DETAILS}

A series of p-type samples with varying $\mathrm{N}$ and In composition were grown by MOCVD and MBE on conductive GaAs substrates. Details about the growth processes are published elsewhere $[5,15,16]$. An ohmic contact was deposited on the back surface, and Schottky contacts formed by sputtered $\mathrm{Au}$ were deposited on the top surfaces. Estimates of $\mathrm{N}$ content were obtained from a combination of measured photoluminescence bandgap and X-ray diffraction [5]. The samples were then characterized by measuring room-temperature carrier concentration using the capacitance-voltage $(\mathrm{C}-\mathrm{V})$ technique [17] at a frequency of $1 \mathrm{MHz}$.

DLTS data were collected using a SULA Technologies [18] instrument, which provides up to 12 rate-windows and measures capacitance at a frequency of $1 \mathrm{MHz}$. Temperature was scanned at a rate of $10 \mathrm{~K}$ per minute, and data for each rate window were collected during both upward and downward temperature sweeps. These data were then averaged to account for any temperature lag between the temperature sensor and the sample.

\section{DISCUSSION}

DLTS data were collected at an applied reverse bias of $1 \mathrm{~V}$, a pulse amplitude of $1 \mathrm{~V}$ (to 0 $\mathrm{V})$, and a pulse width of $10 \mathrm{~ms}$. The data for the $0.2-\mathrm{ms}$ rate window during the heating cycle are shown in figure 1 . The values of $\Delta \mathrm{C}$, the capacitance changes during the rate windows, are converted to trap density by using the relation [19] $\mathrm{N}_{\mathrm{T}}=2 \mathrm{~N}_{\mathrm{a}} \Delta \mathrm{C} / \mathrm{C}$, with $\mathrm{N}_{\mathrm{T}}$ the trap concentration, $\mathrm{N}_{\mathrm{a}}$ the acceptor density determined from room-temperature $\mathrm{C}-\mathrm{V}$ curves, and $\mathrm{C}$ the reverse bias capacitance.

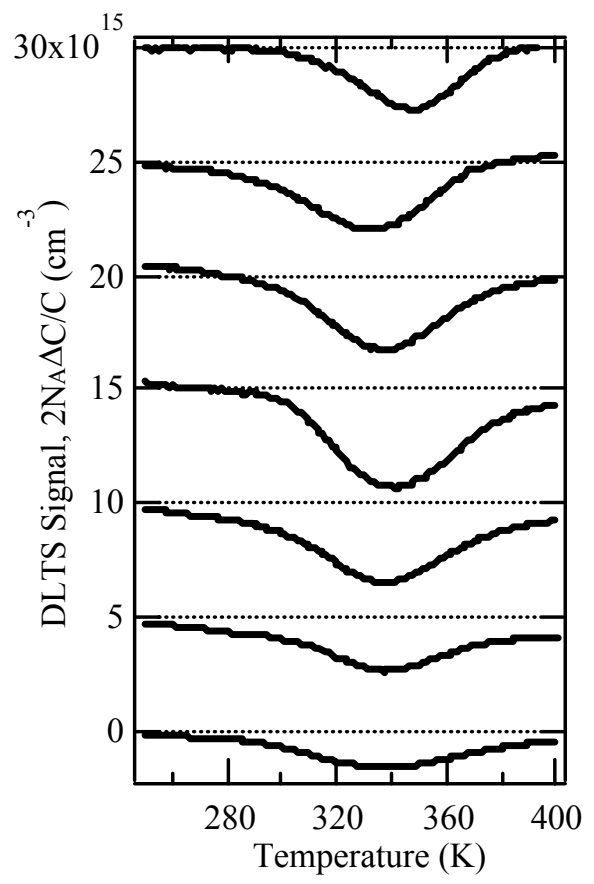

MOCVD GaAs (x30)

MOCVD InGaAs (x30)

MOCVD InGaAs ${ }_{0.996} \mathrm{~N}_{0.004}(\mathrm{x} 10)$

MBE InGaAs $\operatorname{I.994}_{0.006}(\mathrm{x} 3)$

MOCVD InGaAs $\operatorname{In}_{0.98} \mathrm{~N}_{0.02}(\mathrm{x} 3)$

$\operatorname{MOCVD~GaAs}_{0.98} \mathrm{~N}_{0.02}(\mathrm{x} 3)$

MBE InGaAs ${ }_{0.978} \mathrm{~N}_{0.022}(\mathrm{x} 1)$

Figure 1. Trap concentration from DLTS measurement using 0.2-ms rate window. For clarity, each trace is offset by $5 \times 10^{15}$ and multiplied by the factor shown on the right in parentheses. 
A representative DLTS scan of a GaAs sample is shown in the inset of figure 2 and displays data from all 12 rate windows during the heating cycle. The negative peaks correspond to majority-carrier hole traps with a density of about $10^{14} \mathrm{~cm}^{-3}$. The maximum temperature points are then plotted on an Arrhenius plot with the corresponding rate-window time constants, $\tau$, as shown in figure 2. The data points are fit by linear equations, giving slope and intercept values. The activation energies, $\mathrm{E}_{\mathrm{a}}$, are determined from the Arrhenius plots' slope [17] and are also shown in figure 2. The standard deviation of each linear fit corresponds to $\pm 0.005 \mathrm{eV}$. Errors in temperature of $\pm 1 \mathrm{~K}$ would give uncertainties for $\mathrm{E}_{\mathrm{a}}$ of up to $\pm 0.01 \mathrm{eV}$. The $\Delta \mathrm{C}$ data of figure 1 show that each sample contains a hole trap with the peak occurring near $350 \mathrm{~K}$. The corresponding activation energies range from 0.5 to $0.8 \mathrm{eV}$. The amount of added $\mathrm{N}$ ranges from $0 \%$ to $2 \%$, and In is either not included or added in a small percentage proportional to $\mathrm{N}$ to increase lattice matching. Although peaks due to hole traps are consistently seen near $350 \mathrm{~K}$, their calculated activation energies are not a constant value and vary beyond the corresponding fits' standard deviations. The activation energies also do not show a relation to $\mathrm{N}$ content.

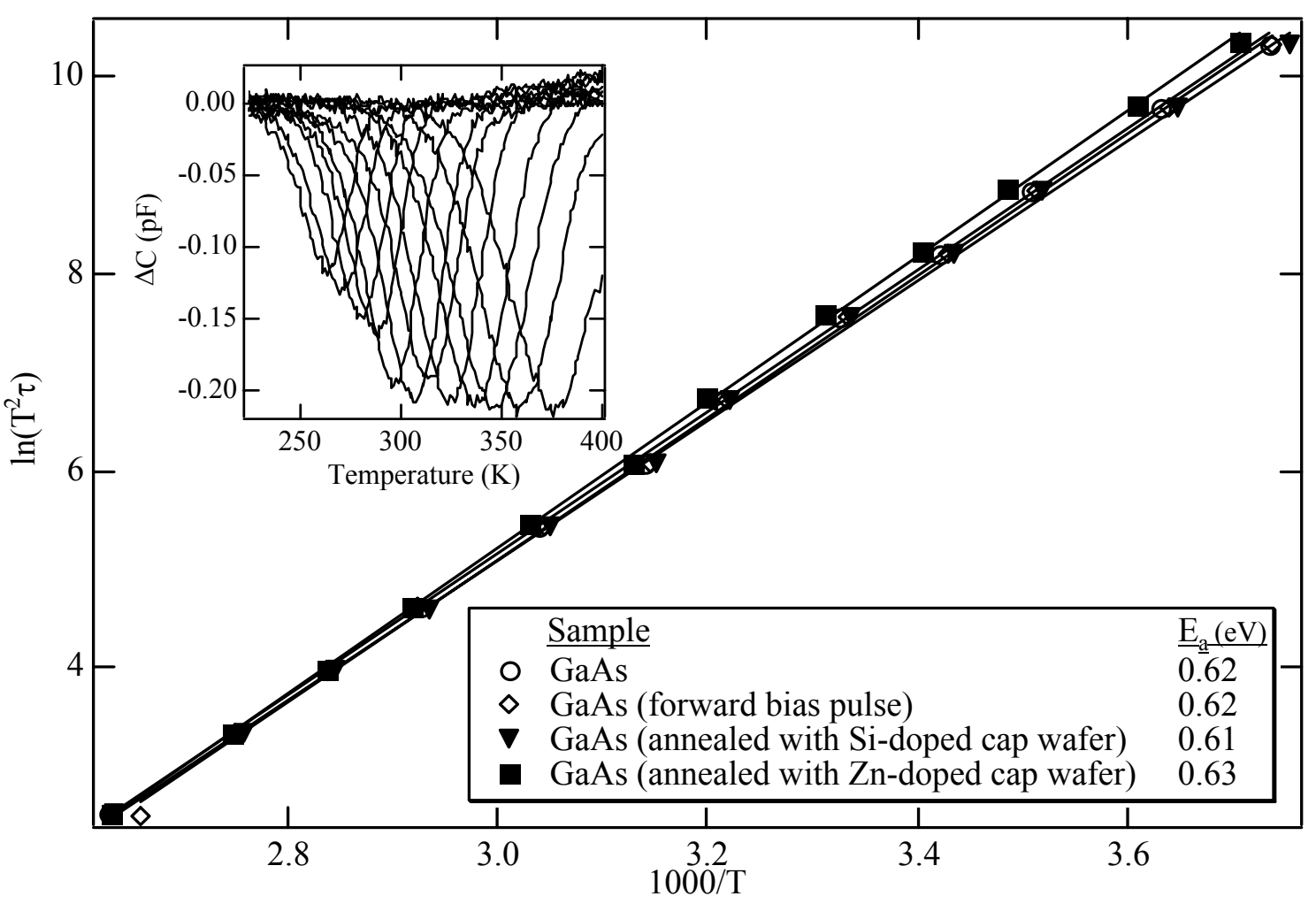

Figure 2. Arrhenius plot for the hole trap in MOCVD-grown GaAs samples. The data points correspond to peak temperature values for the 12 DLTS rate windows. The inset graph shows the hole-trap DLTS signal for the 12 available rate windows.

\section{$\underline{\text { Meyer-Neldel rule }}$}

All alloys studied (GaAs, GaAsN, InGaAs, and InGaAsN) show a deep hole-trap with $\mathrm{E}_{\mathrm{a}}$ varying from 0.5 to $0.8 \mathrm{eV}$. $\mathrm{E}_{\mathrm{a}}$ is found from the expression for carrier emission from a trap, which is given by the following [17]: 


$$
\frac{\mathbf{1}}{\tau}=v_{0} e^{-\frac{\mathbf{E}_{\mathrm{a}}}{\mathbf{k}_{\mathrm{B}} \mathbf{T}}}=\mathbf{N}_{\mathrm{B}} \mathbf{v}_{\mathrm{T}} \sigma \boldsymbol{e}^{-\frac{\mathbf{E}_{\mathrm{a}}}{\mathbf{k}_{\mathrm{B}} \mathbf{T}}}=\gamma \mathbf{T}^{\mathbf{2}} \sigma \mathbf{e}^{-\frac{\mathbf{E}_{\mathrm{a}}}{\mathbf{k}_{\mathrm{B}} \mathbf{T}}}
$$

where $v_{\mathbf{0}}$ is a constant, $\mathrm{k}_{\mathrm{B}}$ is the Boltzmann constant, $\mathrm{N}_{\mathrm{B}}$ is the band density-of-states, $\mathrm{v}_{\mathrm{T}}$ is the thermal velocity, $\sigma$ is the capture-cross section, and $\gamma=\mathrm{N}_{\mathrm{B}} \mathrm{V}_{\mathrm{T}} \mathrm{T}^{-2}$. In addition, the Meyer-Neldel [20] rule (MNR) states that:

$$
\ln \left(v_{\mathbf{0}}\right)=\ln \left(v_{\mathbf{0 0}}\right)+\frac{\mathbf{E}_{\mathbf{a}}}{\mathbf{k}_{\mathbf{B}} \mathbf{T}_{\mathbf{i s o}}} .
$$

Here, $v_{00}$ is a constant and $\mathrm{T}_{\text {iso }}$ is the isokinetic temperature. Substituting Eq. (2) into (1):

$$
\frac{1}{\tau}=v_{00} \mathrm{e}^{\frac{\mathrm{E}_{\text {act }}}{\mathrm{k}_{\mathrm{B}} \mathrm{T}_{\text {iso }}}} \mathrm{e}^{-\frac{\mathrm{E}_{\text {act }}}{\mathrm{k}_{\mathrm{B}} \mathrm{T}}},
$$

which shows that the increase in the term $E_{\text {act }} / \mathrm{k}_{\mathrm{B}} \mathrm{T}_{\text {iso }}$ compensates somewhat for the Boltzmann factor. For this reason the MNR is frequently called the "compensation law" [21]. Each measured sample's linear fit on an Arrhenius plot has a slope $\left(E_{a} / k_{B}\right)$ and a y-intercept value $(\ln (\gamma \sigma))$. These points are plotted in figure 3, and this type of plot is often called a Meyer-Neldel plot. The different growth methods and alloy types are shown by different symbols. The figure clearly shows that $\ln (\gamma \sigma \underline{)})$ varies linearly with $\mathrm{E}_{\mathrm{a}}$ by as much as five orders of magnitude.

Because $\gamma$ is roughly constant over this alloy range, we might conclude that $\sigma$ varies by orders of magnitude for what could be the same defect in the different alloys.

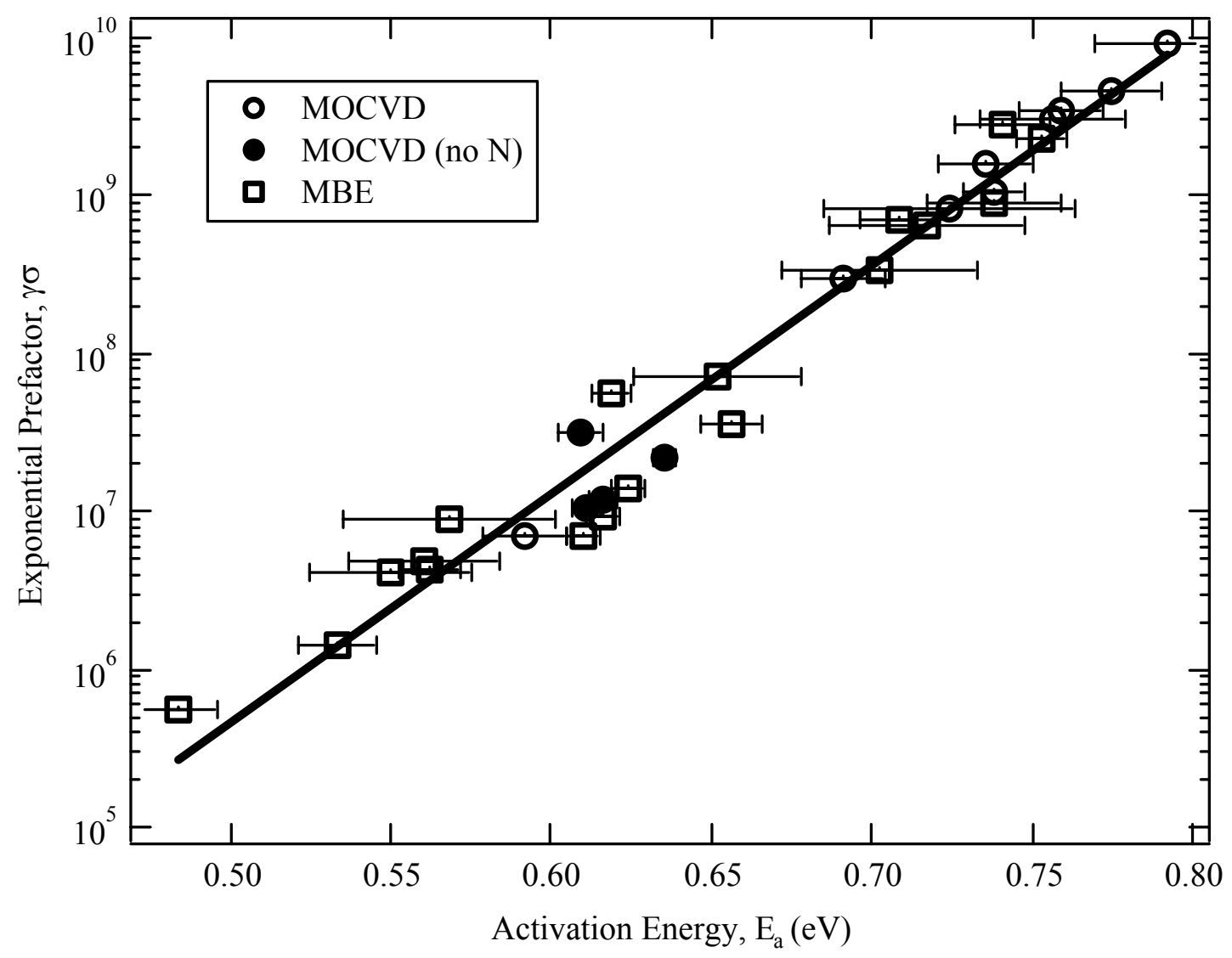

Figure 3. MNR plot of DLTS determination of the exponential prefactor, $\gamma \sigma, v s . E_{a}$ for the principal deep hole-trap. Note that the vertical axis is logarithmic. 
A consequence of the MNR is that at $T=T_{\text {iso }}$ the detrapping rate is independent of $E_{a}$. According to the MNR, the slope of a line through the data in figure 3 is $\left(k_{B} T_{\text {iso }}\right)^{-1}$. A leastsquare-error fit of the data gives $T_{\text {iso }}=350 \pm 15 \mathrm{~K}$. Then, when the material is at this temperature, both shallow and deep levels may have the same detrimental impact on device performance because their emission rates are similar.

The MNR has been addressed by many articles [22-24], including one by Crandall in this conference proceedings [25]. The physical explanation of this rule is based on the realization that there is considerable entropy, $\Delta \mathrm{S}_{\mathrm{ph}}$, associated with the assembly of a large number of system excitations at a particular site to produce a thermally activated jump over an energy barrier [22-25]. The following expression [26] shows the emission rate with the entropy contribution:

$$
\frac{1}{\tau}=\mathrm{N}_{\mathrm{C}} \mathrm{V}_{\mathrm{T}} \sigma \mathrm{e}^{-\frac{\Delta \mathrm{G}}{\mathrm{k}_{\mathrm{B}} \mathrm{T}}}=\mathrm{N}_{\mathrm{C}} \mathrm{V}_{\mathrm{T}} \sigma \mathrm{e}^{-\frac{\Delta \mathrm{H}-\mathrm{T} \Delta \mathrm{S}}{\mathrm{k}_{\mathrm{B}} \mathrm{T}}} .
$$

Here, $\Delta \mathrm{G}$ is the change in Gibbs free energy, $\Delta \mathrm{H}=\mathrm{E}_{\mathrm{a}}$, and $\Delta \mathrm{S}$ is the entropy change. If we assume that the only entropy contribution to the free energy is the phonon entropy from MNR, that is, $\Delta \mathrm{S}=\mathrm{E}_{\mathrm{a}} / \mathrm{T}_{\text {iso }}$, we see that Eq. (4) is equivalent to Eq. (3), the MNR. Knowledge of $\sigma$ permits determination of this entropy, and by correctly accounting for this entropy term, we see that $\sigma$ is the same for all traps that fall along the MNR line. This is reasonable because we expect that the trap will correspond to the same defect for the range of alloys presented here. Using the known physical constants [27], we find that $\sigma=2 \times 10^{-23} \mathrm{~cm}^{2}$. This value is exceedingly small, but in line with that found by others who observed the MNR in similar alloys [28,29]. Some preliminary results from measuring capture rate by varying the filling pulse time [17] suggest that $\sigma$ is temperature dependent following a model of a Coulomb-repulsive center having a potential barrier [30]. We plan to measure $\sigma$ as a function of temperature, and use those results to calculate more accurate values of entropy, defect energy level, and trap potential barrier.

\section{SUMMARY}

We have used DLTS to measure hole traps in a series of p-type InGaAsN alloys grown by MOCVD and MBE methods. Hole traps were seen in each sample and may be attributed to a native defect or defect complex. All data presented above show that carrier emission obeys the Meyer-Neldel Rule with an isokinetic temperature of $350 \mathrm{~K}$.

\section{ACKNOWLEDGMENTS}

The authors thank Aaron Ptak, Daniel Friedman, and Sarah Kurtz for the various samples. The U.S. Department of Energy supported this work under Contract No. DE-AC36-99GO10337.

\section{REFERENCES}

1 M. Weyers, M. Sato, and H. Ando, Jpn. J. Appl. Phys. 31, 853 (1992).

2 W. G. Bi and C. W. Tu, Appl. Phys. Lett. 70, 1608 (1997).

3 I. A. Buyanova, W. M. Chen, G. Pozina, B. Monemar, H. P. Xin, and C. W. Tu, Phys. Stat. Sol. (b) 216, 125 (1999). 
4 M. Kondow, K. Uomi, A. Niwa, T. Kitatani, S. Watahiki, and Y. Yazawa, Jpn. J. Appl. Phys. 35, 1273 (1996).

5 J. F. Geisz, D. J. Friedman, J. M. Olson, S. R. Kurtz, and B. M. Keyes, J. Cryst. Growth 195 (1-4), 401 (1998).

6 S. R. Kurtz, D. Myers, and J. M. Olson, presented at the 26th IEEE Photovoltaic Specialists Conference, Anaheim, CA, 1997 (unpublished).

7 E. D. Jones, A. A. Allerman, J. F. Klem, S. R. Kurtz, N. R. Modine, D. J. Friedman, J. F. Geisz, W. Shan, W. Walukiewicz, and C. Tu, Electrochemical Society International Symposium, 1999.

8 P. Krispin, S. G. Spruytte, J. S. Harris, and K. H. Ploog, Physica B 308, 870 (2001).

9 P. Krispin, S. G. Spruytte, J. S. Harris, and K. H. Ploog, J. Appl. Phys. 89, 6294 (2001).

10 K. M. Chen, Y. Q. Jia, Y. Chen, A. P. Li, S. X. Jin, and H. F. Liu, J. Appl. Phys. 78, 4261 (1995).

11 D. Kwon, R. J. Kaplar, S. A. Ringel, A. A. Allerman, S. R. Kurtz, and E. D. Jones, Appl. Phys. Lett. 74, 2830 (1999).

12 R. J. Kaplar, D. Kwon, S. A. Ringel, A. A. Allerman, S. R. Kurtz, E. D. Jones, and R. M. Sieg, Solar Energ. Mater. Solar Cells 69, 85 (2001).

13 R. J. Kaplar, S. A. Ringel, S. R. Kurtz, J. F. Klem, and A. A. Allerman, Appl. Phys. Lett. 80, 4777 (2002).

14 S. W. Johnston, presented at the IEEE PVSC, New Orleans, LA, 2002 (unpublished).

15 D. J. Friedman, J. F. Geisz, S. R. Kurtz, and J. M. Olson, $2^{\text {nd }}$ World Conference and Exhibition on Photovoltaic Solar Energy Conversion (1998).

16 A. J. Ptak, D. J. Friedman, and S. W. Johnston, MBE-XII, September 15-20, 2002, San Francisco, CA, pp. 291-292.

17 P. Blood and J. W. Orton, The Electrical Characterization of Semiconductors: Majority Carriers and Electron States. (Academic Press, 1992), pp. 343-345 and pp. 607-612.

18 Sula Technologies, PO Box 963, Ashland, OR 97520, USA

19 D. V. Lang, J. Appl. Phys. 45 (7), 3023 (1974).

20 W. Meyer and H. Neldel, Z. Tech. Phys. 12, 588 (1937).

21 R. W. Keyes, J. Chem. Phys. 29, 467 (1958).

22 A. Yelon, B. Movaghar, and H. M. Branz, Phys. Rev. B 46, 12244 (1992).

23 A. Yelon and B. Movaghar, Phys. Rev. Lett. 65, 618 (1990).

24 E. Peacock-Lopez and H. Suhl, Phys. Rev. B 26, 3774 (1982).

25 R. S. Crandall, presented at the 2003 MRS Spring Meeting, San Francisco, CA, (Mater. Res. Soc. Proc., Pittsburgh, PA, 2003).

26 O. Engstrom and A. Alm, Solid-State Electron. 21, 1571 (1978).

27 D. K. Schroeder, Semiconductor Material and Device Characterization, 2nd ed. (John Wiley \& Sons, Inc., New York, NY, 1998), p. 280.

28 K. L. Narasimhan and B. M. Arora, Solid State Commun. 55, 615 (1985).

29 I. Thurzo and J. Ivanco, Applied Surface Science 108 (1), 187 (1997).

30 A. Rose, Concepts in Photoconductivity and Allied Problems, (Robert I. Krieger Publishing Co., Inc., New York, 1978), pp. 126-127. 


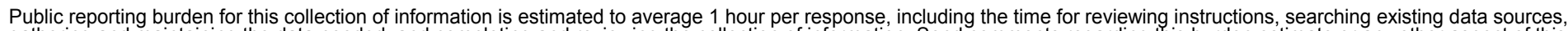

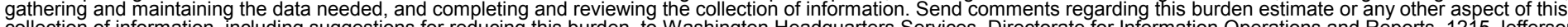
Davis Highway, Suite 1204, Arlington, VA 22202-4302, and to the Office of Management and Budget, Paperwork Reduction Project (0704-0188), Washington, DC 20503.
1. AGENCY USE ONLY (Leave blank)
2. REPORT DATE
April 2003
3. REPORT TYPE AND DATES COVERED Conference paper

4. TITLE AND SUBTITLE

Evidence of the Meyer-Neldel Rule in InGaAsN Alloys: Consequences for Photovoltaic Materials; Preprint

5. FUNDING NUMBERS PVP33101

6. $\operatorname{AUTHOR}(\mathrm{S})$

S.W. Johnston and R.S. Crandall

7. PERFORMING ORGANIZATION NAME(S) AND ADDRESS(ES)

National Renewable Energy Laboratory

1617 Cole Blvd.

8. PERFORMING ORGANIZATION REPORT NUMBER

Golden, CO 80401-3393

NREL/CP-520-33229

9. SPONSORING/MONITORING AGENCY NAME(S) AND ADDRESS(ES)

10. SPONSORING/MONITORING AGENCY REPORT NUMBER

11. SUPPLEMENTARY NOTES

12a. DISTRIBUTION/AVAILABILITY STATEMENT

National Technical Information Service

12b. DISTRIBUTION CODE

U.S. Department of Commerce

5285 Port Royal Road

Springfield, VA 22161

13. ABSTRACT (Maximum 200 words): We present data showing the potential adverse effects on photovoltaic device performance of all traps in InGaAsN. Deep-level transient spectroscopy measurements were performed on InGaAsN samples grown by both metal-organic chemical vapor deposition and RF plasma-assisted molecular-beam epitaxy. For each growth technique, we studied samples with varying nitrogen composition ranging from $0 \%$ to $2.2 \%$. A deep hole trap with activation energy ranging between 0.5 and $0.8 \mathrm{eV}$ is observed in all samples. These data clearly obey the Meyer-Neldel rule, which states that all traps have the same emission rate at the isokinetic temperature. A fit of our trap data gives an isokinetic temperature of $350 \mathrm{~K}$, which means that both deep and shallow traps emit slowly at the operating temperature of solar cells-thus, the traps can be recombination centers.

14. SUBJECT TERMS: PV; Meyer-Neldel Rule; deep-level transient spectroscopy (DLTS); metal-organic chemical vapor deposition (MOCVD); RF plasma-assisted; molecularbeam epitaxy (MBE); InGaAsN; isokinetic temperature;

15. NUMBER OF PAGES

16. PRICE CODE

17. SECURITY CLASSIFICATION OF REPORT Unclassified

18. SECURITY CLASSIFICATION OF THIS PAGE Unclassified
19. SECURITY CLASSIFICATION OF ABSTRACT Unclassified
20. LIMITATION OF ABSTRACT

UL 